\title{
Att samhandla med manualer: föränderliga deltagare i skolors hälsofrämjande arbete
}

Karin Gunnarson

Institutionen för de humanistiska och samhällsvetenskapliga ämnenas didaktik (HSD), Stockholms universitet

\begin{abstract}
I denna text ställs frågor om hur skolors hälsofrämjande arbete formas och blir till tillsammans med manualer. Syftet är att undersöka vad manualerna gör och hur de görs som samhandlande aktörer i detta arbete. Genom att studera händelser i ett manualbaserat program med aktör-nätverksteori blir fokus hur manualer, elever, gruppledare, klassrum och känslor samverkar och samskapas i det hälsofrämjande arbetet. I analysen framkommer hur manualer sammankopplade i nätverk blir till en trygg aktör, en aktör som tillsammans med evidens och forskning erbjuder kunskap om de elever som deltar och hur hälsa ska främjas. De blir samtidigt obekväma och stressande aktörer. Analysen visar hur manualerna samtidigt blir poröst konstruerade och stabilt fixerande. Med denna förståelse av hur manualerna inverkar i det hälsofrämjande arbetet blir det svårt att förutse dess effekter och verkningar. Ambitionen måste då vara att utforma ett hälsofrämjande arbete med engagemang och experimenterande, en praktik där många berättelser och världar kan ta form.
\end{abstract}

\section{INLEDNING}

De senaste decennierna har rapporter om ökad ohälsa bland barn och unga kommit parallellt med ökade krav på skolan att arbeta med hälsofrämjande insatser. Skolan lyfts fram som en institution med uppdraget att förebygga och åtgärda de psykiska och fysiska problem som unga förväntas utveckla eller ha (se t.ex. Skolinspektionen, 2015; Skolverket, 2016). De ökade kraven på skolors hälsofrämjande arbete har inneburit att strukturerade och universella metoder allt oftare används. För att säkerställa att dessa metoder är effektiva och tillförlitliga måste de vara beprövade och evidensbaserade 
(SBU, 2010). Detta har i sin tur inneburit att skolan blivit "ett slags laboratorium" där preventionsprogram implementeras och utvärderas (Ferrer-Wreder m.fl., 2005, s. 136). Med föresatsen om att använda evidensbaserade metoder i skolans hälsofrämjande arbete blir manualbaserade metoder och manualtrohet något önskvärt. Det är genom att följa manualer som forskare, framförallt inom folkhälsovetenskap, menar att det går att få kunskap om "metodens värde att främja hälsa" (Jablonska \& Heinemans, 2011, s. 8). En fråga jag ställer i denna text är om evidens och manualtrohet kan garantera bra och omsorgsfulla insatser för ungas hälsa. Går det att i stället för att undersöka om metoder är effektiva eller inte, undersöka vad de producerar eller vilka effekter de är medskapare av (jfr Mol, 2006)? Det innebär att ta avstamp i utbildningsfilosofen Gert Biestas påstående om att "what works won't work" för att undersöka hur "what works" (2007, s. 1) verkar och fungerar. Vad sker och skapas i detta laboratorium, i samverkan mellan manualer, skolpersonal, elever och klassrum?

För att besvara dessa frågor kommer jag i denna text att sätta fokus på hur en hälsofrämjande praktik tar form tillsammans med manualer. Syftet är att undersöka vad manualerna gör och hur de görs såsom samhandlande aktörer i skolors hälsofrämjande arbete. Detta syfte utgår från att manualerna är ting men ting som med aktör-nätverksteori förstås som aktiva och föränderliga. Utifrån detta syfte ställs två forskningsfrågor: hur blir manualerna, sammankopplade i ett nätverk av olika aktörer, del av att forma det hälsofrämjande arbetet? Och, hur formar manualerna regleringar och möjligheter?

\section{Skolors hälsofrämjande arbete}

Skolors hälsofrämjande arbete kan ses som kopplat till värdegrundsuppdraget som introducerades i början av 1990-talet. Sedan värdegrundsuppdraget infördes har det till viss del fått en förändrad karaktär, från att handla om demokrati och mänskliga rättigheter till att idag även omfatta elevers känslor och välmående (Bergh \& Englund, 2014; Gunnarsson, 2015). Skolverket skriver i ett stödmaterial kring värdegrunden att "där barn och elever får lust att lära, känner trygghet och får framtidstro är det hälsofrämjande arbetet en del av värdegrundsuppdraget - och inte skilt från kunskapsuppdraget” (2011, s. 104). På så vis sammanvävs det hälsofrämjande arbetet med såväl skolans kunskapsuppdrag som värdegrundsuppdrag.

Vissa forskare menar att skolans betoning av hälsa och känslor är ett uttryck av en terapeutisk kultur som utgår från att barn och unga är särskilt sårbara (se t.ex. Ecclestone, 2015; Wright, 2015). Denna kultur, menar dessa forskare, formar förgivet tagna sanningar om normalitet och autonomi. Med terapiliknande undervisning disciplineras barn och unga mot specifika sätt att vara. Denna kultur har även blivit del av en marknadifiering av värdegrundsarbetet som öppnat upp för olika aktörer att införa terapeutiska 
metoder i skolan (jfr Brunila, 2014; Irisdotter Aldenmyr, 2014; Kvist Lindholm \& Zetterqvist Nelson, 2015).

Ett av de manualbaserade program som används inom svensk skola och som är del av denna studie är DISA (Depression in Swedish adolescence/Din inre styrka aktiverad). DISA bygger på kognitiv-beteendepsykologi och syftar till att förebygga psykisk ohälsa framförallt bland flickor. Det beskrivs som ett universellt program och riktas till alla flickor utifrån antagandet om att hela gruppen löper risk att drabbas av ohälsa (Treutiger \& Lindberg, 2012). Programmet består av tio träffar som struktureras av två manualer. Det är dels en gruppledarmanual med instruktioner till gruppledaren, dels en elevmanual som ges till varje elev och innehåller övningar som ska genomföras. Dessa övningar handlar om att träna kognitiva och beteendemässiga färdigheter till exempel att lära sig kontrollera och hantera tankar och känslor. Programmets strukturerade och manualstyrda utformning ska fungera som en form av undervisning och vara enkel att utföra även för den som inte är erfaren inom kognitiv beteendeterapi (ibid.). Folkhälsoforskaren Pernilla Garmy har i sin avhandling undersökt DISA med en kombination av kvalitativa och kvantitativa metoder. Studien visar resultat som "tyder på att DISA minskar depressiva symtom och stärker ungdomars självskattade hälsa" (Garmy, 2016, s. 73). Avslutningsvis frågar Garmy om det är manualerna som ligger till grund för tendensen till ökad hälsa bland deltagarna eller om det hade fungerat lika bra med ostrukturerade träffar (ibid., s. 76).

Två andra studier genomförda av Sofia Kvist Lindholm och Karin Zetterqvist Nelson (2015) och Anette Wickström (2012) har undersökt DISA med utgångspunkt i ett barndomsperspektiv. Kvist Lindholm och Zetterqvist Nelson (2015) utgår från ett diskursanalytiskt perspektiv och studerar hur DISA-programmet är konstruerat i och genom text och prat. Studien visar på problemen med att utgå från ett behandlande program och omarbeta det till ett förebyggande såsom gjorts med DISA. Problematiken, enligt Kvist Lindholm och Zetterqvist Nelson, är de antaganden om att deltagarna har negativa tankar och problem som finns i behandlingsprogrammen men som inte nödvändigtvis finns hos de individer som deltar. Här finns en risk att DISA "reinforces stereotypical notions of girls as depressive and as having low self-esteem" (ibid., s. 10) vilket kan leda till att programmet snarare skapar ohälsa än främjar hälsa. Anette Wickström (2012) visar i sin studie hur gruppledare och deltagare omformar DISA-praktiken och förskjuter dess innehåll från en stark individcentrering till att också beakta sociala relationer. Genom att frångå manualen och diskutera det som var viktigt i stunden kunde DISA bli meningsfullt för deltagarna. Utifrån detta ställer Wickström frågan huruvida programmet gör någon nytta eller om det vore bättre att utgå från elevernas vardag och faktiska problem (ibid.).

För att sammanfatta denna begränsade genomgång av tidigare forskning kring skolors hälsofrämjande arbete och det manualbaserade programmet 
DISA vill jag peka på två olika forskningsfält. Det är dels folkhälsovetenskapliga studier som förespråkar och utvärderar manualbaserade program utifrån antaganden om att dessa går att kontrollera och mäta. Det är dels kritiska studier med antaganden om att dessa insatser formas av diskurser och som påvisar de hälsofrämjande insatsernas disciplinerande effekter (jfr Gunnarsson, 2015). Båda dessa forskningsfält ställer viktiga frågor som jag tar med mig vidare i denna text. Här blir dock ansatsen att skapa kunskap om hur manualer, kroppar, känslor och klassrum samverkar och tillsammans formar det hälsofrämjande arbetet. För att göra det arbetar jag med aktörnätverksteori och framförallt med filosofen Annemarie Mols arbete. En central ingång blir då hur skolors hälsofrämjande arbete kan ta form när vi inkluderar vitaliteten och kraften $i$ såväl mänskliga som icke-mänskliga aktörer.

\section{AKTÖR-NÄTVERKSTEORI - EN TEORETISK OCH METODOLOGISK HÅLLNING}

Aktör-nätverksteori (ANT) har sitt ursprung i antropologi och sociologi och har använts för att undersöka både hälso- och skolpraktiker. Trots namnet beskriver filosofen Annemarie Mol ANT snarare som en teoretisk och metodologisk hållning än en teori. Det syftar inte till att tillhandahålla fasta utgångspunkter eller begrepp utan att fungera som en föränderlig och öppen arsenal att tänka med. ANT blir då en ontologisk hållning med begrepp eller principer $^{1}$ som förstås som delaktiga $\mathrm{i}$ att omvandla varandra, det empiriska materialet och mig som forskare. I analysen i denna text blir begreppen nätverk, utrymme och blivande aktiva i utforskandet av hur manualerna är delaktiga i skolors hälsofrämjande arbete.

Med utgångspunkt i det sociala görs med ANT en utvidgning till att också innefatta hur verkligheter görs genom relationer och praktiker samt hur materialiteter och diskurser, mänskliga och icke-mänskliga aktörer, samverkar i dessa göranden. Ett viktigt antagande blir här att ingen aktör, varken mänsklig eller icke-mänsklig, kan handla på egen hand. Utifrån detta antagande är det $\mathrm{i}$ relationer och praktiker som göranden, blivande och förändring sker (Mol, 2010). Ting såsom manualer blir mer än passiva objekt. De blir medaktörer som samhandlar och samskapas med andra aktörer. Människor har således inte någon fullständig kontroll över vad som händer $\mathrm{i}$ en praktik såsom $i$ hälsofrämjande arbete. Praktiken konstitueras $i$ en sammanvävd relation mellan människor och materialiteter. Det innebär att hälsofrämjande arbete blir något mer än sociala relationer och även omfattar rum, kroppar, känslor, tal och kunskaper. Detta innebär vidare att manualerna som ting i det hälsofrämjande arbetet blir till genom de relationer där de ingår. Haraway beskriver det som "att vara någon är alltid att bli tillsammans med 
många" (2011, s. 175). Blivande är inget som sker slumpmässigt men inte heller som statiska eller kausala samband. Det sker i processer av omformningar och upprepningar som inbegriper både möjligheter och begränsningar. Vad som här blir centralt är att manualen alltså är aktiv och föränderlig - den blir till, gör och görs, tillsammans med andra.

Ett sätt att med ANT undersöka hur dessa processer av blivande sker är att studera de nätverk där de tar form. Nätverk är de föränderliga och komplexa sammankopplingar där såväl forskare som verklighet samskapas och samhandlar. I och genom nätverk formas aktörers möjligheter att agera och förändras (Mol, 2010). Mol beskriver det som att aktörer blir till, förbinds med varandra och formar "a network in which they all are made into "actors" as the associations allow each of them to act" (2010, s. 260). Genom associationer förenas och möts aktörer vilket skapar nätverk som samtidigt $i$ en reciprok relation skapar aktörer. I och genom nätverk blir manualerna till, i en samtidighet formade av nätverk och del av att forma nätverk. I dessa nätverk formas ett specifikt utrymme (jfr eng. space) där vissa göranden tankar, känslor och kroppar - blir möjliga. Den utbildningsvetenskapliga aktör-nätverksteoretikern Tara Fenwick menar att nätverk avser att "invoke the simple but plastic concept of an unspecified set of connected points or nodes with un-represented spaces among them" (2011, s. 119). Dessa utrymmen skapar öppningar där flöden och rörelser ger möjlighet för nätverket att förändras och omformas (se också Mol, 2010). Ett utrymme är inte ett rum eller en plats som utformas och används. Det blir en specifik materiell och diskursiv rumslighet delaktig $i$ att forma hur ting och människor blir till och förhåller sig till varandra. Att undersöka hur det hälsofrämjande arbetet tillsammans med manualer skapar nätverk med specifika utrymmen och spelrum ger här en öppning till att skapa kunskap om hur manualerna blir del av både regleringar och möjligheter i det hälsofrämjande arbetet.

En ytterligare ansats i denna text är att lyfta fram hur känslor samverkar och samskapas i nätverket. Med utgångspunkt i affekt-teori blir känslor en relationell intensitet och kraft. De blir kollektiva och rörliga krafter med effekter för såväl kroppar som världar (Seigworth \& Gregg, 2010). Formade av affektiva, kognitiva, diskursiva och materiella komponenter blir känslor del av de möten och beröringar som skapas genom kroppens relationer till omgivningen (Gunnarsson, 2015). Vad som i denna studie blir viktigt är att inte bortse från eller ignorera känslor utan inkludera dem i kunskapandet av hur manualerna gör och hur de görs. Det innebär ett försök att undersöka hur diskurser, materialiteter, kroppar och känslor är sammanvävda och samverkande i det hälsofrämjande arbetet.

\section{Empiriska framkallningar och spåranden}

I relation till aktör-nätverksteori är studiens metodologi inspirerad av vad som beskrivits som en post-kvalitativ ansats (se t.ex. Lather \& St. Pierre, 2013). 
Det innebär att utmana en vanligt förekommande uppdelning av verkligheten och beskrivningar av verkligheten där språk ses som representationer. En forskningspraktik kan enligt den postkvalitativa ansatsen aldrig upptäcka eller blotta vad som redan finns utan är del av att producera det som studeras. Därför går det inte att särskilja kunskap om världen och världen i sig. Händelser äger rum och framträder sammanvävt med såväl forskarens deltagande engagemang som teori och tidigare forskning. Jag har tidigare beskrivit detta som att ett empiriskt material "framkallas på samma sätt som en fotograf framkallar bilder i ett mörkrum" (Gunnarsson, 2015, s. 78). Det empiriska materialet tar form och framträder genom forskarens engagemang i praktiker och händelser såsom intervjuer och deltagande observationer.

Det empiriska materialet i denna text är producerat i samband med mitt avhandlingsarbete (se Gunnarsson, 2015). Materialet består av deltagande i DISA-träffar på tre skolor, fem intervjuer med skolpersonal som fungerade som gruppledare samt fem gruppintervjuer med sammanlagt 21 elever. ${ }^{2}$ De gruppledare som ingår i denna artikel är Sara, Nina och Caroline som arbetade som skolkuratorer, Tina som arbetade som fritidshemslärare, samt Kristina och Anna som var lärare och arbetade på samma skola. I elevgruppen ingår Anna, Louise, Miriam, Emma, Tanja, Janina, Evelyn och Nicki som alla gick i årskurs åtta på två olika skolor och som deltagit i DISA-träffar. ${ }^{3}$ Intervjuerna med eleverna skedde efter den sista DISA-träffen, i skolan under elevernas raster. Vid intervjuerna hade jag med DISA-programmets elevmanual som en ytterligare aktör. Med aktör-nätverksteori blir intervjun en händelse som sammanväver och skapas tillsammans med tidigare händelser på DISAträffarna. Det som sägs i en intervju förstås som berättelser om händelser som de intervjuade har deltagit $\mathrm{i}$ och inte enbart som konstruktioner där och då eller som ett utforskande av intervjupersonernas perspektiv eller åsikter (Mol, 2002).

I denna text blir ett analytiskt fokus att spaira hur manualerna blir till, förändras och agerar i praktiker och händelser. Spårningen blir en form av kartläggning av den mångfald av aktörer som i samverkan med manualerna skapar det hälsofrämjande arbetet (Latour, 2005; se också Gunnarsson, 2015). Det blir en process som tar form genom sammankopplingar av flera olika praktiker. Empiriskt material, tidigare forskning och teori formar en kunskapsproducerande apparatur delaktiga $\mathrm{i}$ att forma den spårande analysen. Utifrån studiens syfte innebär analysen att spåra hur manualerna görs och samtidigt vad de gör tillsammans med andra aktörer sammankopplade i nätverk. Genom spårningen framkommer hur gruppledare, skola och tid blir framträdande aktörer i relation till manualerna. Det är utifrån dessa aktörer och relationer som analysen struktureras. 


\section{ATTT BLI TILL MED MANUALER I HÄLSOFRÄMJANDE ARBETE}

Såsom redogjordes för inledningsvis får manualer återkommande en betydande roll i skolors hälsofrämjande arbete. I DISA-programmet ges instruktioner om att gruppledaren ska följa manualerna som formulerar och instruerar ett strukturerat innehåll för de tio träffarna. Detta skedde dock på olika sätt i de praktiker där jag deltog. Sammankopplade i nätverk med en mängd aktörer skedde ett blivande av såväl manual som gruppledare. Gruppledaren Kristina säger att hon och kollegan Anna försöker att följa manualen "väldigt noga".

Kristina: Vi försöker använda manualen väldigt noga faktiskt.

Anna: Ja, förutom det vi har tagit bort.

Kristina: För i och med att man har DISA-programmet, utbildningen, det

känns tryggt. Vi känner oss trygga i det.

Att ha ett program och en manual att följa skapar trygghet till det hälsofrämjande arbetet berättar Kristina. Detta sker i ett nätverk av utbildning, program och manual. Denna trygghet formas genom en ömsesidig relation av att manualen ska följas och att följa manualen. Gruppledare och manual formar associationer som möjliggör ett specifikt agerande (jfr Mol, 2010). Detta ger stabiliserande effekter i det hälsofrämjande arbete där manualen blir till en aktör med stor inverkan. I intervjuerna framkom att gruppledarna strävade efter att följa manualerna men att det av olika anledningar var svårt att göra det. Skäl som uppgavs var att tiden inte räcker till, att många övningar upprepas eller var svåra och krångliga både för dem själva och för eleverna. Även om gruppledarna menade att de följer manualen skapas samtidigt spänningar kring hur mycket det är möjligt att avvika från manualen och fortfarande vara trogen programmet.

\footnotetext{
Sara: Jag kör ganska mycket efter manualen. [...] Men sen finns det ju vissa delar som jag tycker är jättebökiga och när jag inte känner mig bekväm med och inte riktigt förstår det så har jag ju jättesvårt att förmedla det på ett vettigt sätt så då tar vi lite skutt. Också för att det är ett stort material och det är svårt att få in det. Men man har ju en tanke med hur man satt ihop programmet och man har forskat på det och sett att det ger resultat. Då känns det ju att jag inte ska avvika för mycket.
}

I det Sara berättar blir vissa delar av manualen svårtillgängliga och krångliga att förmedla till eleverna. Dessa övningar gör att Sara känner sig obekväm och då hoppar över dem. I relation till eleverna blir manualen inte möjlig att följa eftersom den innehåller svåra och bökiga delar. Relationen till eleverna blir 
del av att forma genomförandet och manualen blir tillfälligt åsidosatt. Även omfattningen av manualen och att det är svårt att få in alla delar gör att vissa delar utelämnas. Manualen beskärs och formas i relation till det utrymme som nätverket erbjuder. Samtidigt finns en stark tilltro till manualen kopplat till forskning som hävdar programmets positiva resultat. På så vis sammankopplas manualer, gruppledare och evidens. Att följa manualen, "inte avvika för mycket", blir något som eftersträvas. I detta nätverk uppstår en rad spänningar som gör manualen porös och föränderlig. Samtidigt trygg, stabil, effektiv och bökig, omfattande och svår. På liknande sätt formas ett specifikt utrymme $\mathrm{i}$ relationen mellan gruppledaren Tina och manualen som ger specifika ordnanden men också föränderliga göranden.

Tina: DISA är ju ett extremt material på det viset att du ska följa det till punkt och pricka. Du ska läsa i princip, alltså det står med fet text det du ska säga vilket är för mig helt omöjligt. Alltså jag kan inte jobba på det viset, då skulle inte Tina vara Tina, då skulle hon va nån helt mycket tråkig människa och då skulle inte DISA bli bra för mig, jag är helt övertygad.

Här blir manualen ett "extremt" material som ställer krav om att följas "till punkt och pricka". Detta sker när Tina betonar hur manualen uppmanar till att läsa det som står i den. Samtidigt finns ett visst utrymme att handla inom och möjligheter att frångå manualens anvisningar. Det blir "helt omöjligt" att följa manualen eftersom Tina menar att hon inte kan arbeta på det sättet och att det dessutom skulle göra henne till en tråkig person. I relation till manualen formas spänningar kring att följa anvisningarna men att då bli till en individ som inte överensstämmer med den Tina anser sig vara. Detta skulle också påverka och ge effekter för praktiken. Med en övertygelse om att DISA inte skulle bli bra om hon följde manualen frångår Tina manualens anvisningar. Manualens logik bygger på en individ som kan reproducera och tillgodose dess önskningar och ordnanden, en individ som gör vad manualen säger åt den att göra. Men såsom framkommer i händelsen ovan fungerar inte manualen på detta sätt. I nätverket formas ett utrymme med möjlighet för ett ambivalent och oförutsägbart blivande (Fenwick, 2011). När Tina menar att hon i relation med manualerna blir någon annan visar det på kraften och föränderligheten som formas genom denna relation. Med aktör-nätverksteori handlar detta inte om ifall Tina kan vara sig själv eller inte i relation till manualen. Inte heller huruvida hennes specifika egenskaper och värderingar överensstämmer med manualen (jfr Mol, 2011). Istället skapas denna händelse i och med det utrymme där både manualen och Tina blir till och samhandlar, ett utrymme med "flux and instability embedded within and floating apart from the network" (Fenwick, 2011, s. 131). Sammankopplade i föränderliga nätverk blir Tina och manualen till i de relationer och praktiker 
som där tar form. Detta sker genom samhandlingar som både skapar och skapas av de ting, kroppar och diskurser som görs aktiva (Haraway, 2004).

\section{Mötet mellan manual, elever och skola}

På liknande sätt skapas i DISA-praktiken en önskan om att eleverna ska göra de övningar som manualen innehåller och då bli medvetna om sina negativa tankar och få en ökad hälsa. Detta sker utifrån antaganden att eleverna har negativa tankar som behöver åtgärdas. Övningarna i DISA innefattar upprepade göranden där eleverna en och en ska skriva ner och arbeta med negativa tankar, ibland utifrån egna exempel och ibland exempel som anges $i$ manualen. Dessa negativa tankar ska skrivas ner i elevmanualen för att de ska förändras, bland annat genom att komma på positiva mottankar till den negativa tanken. Att fylla i papper är en ofta förekommande praktik i skolan men här handlar det om frågor utan koppling till traditionella skolämnen. Frågorna rör istället hälsa och mående sammankopplat med terapeutiska och själv-reflekterande artikulationer. Vid en intervju med en grupp elever framkom hur platsen gjorde det svårt eller omöjligt att besvara manualens frågor.

Anna: Skrivdelen var jobbig.

Louise: Jag skrev ingenting i min bok.

Miriam: Att sitta och skriva i en grupp så här, man är på helt fel ställe i

hjärnan för att sitta och tänka på vad som händer. Det blev jätteförvirrande att sitta och skriva.

Eleverna uttrycker att de haft svårt att lösa uppgifterna och Louise uttrycker att hon inte skrivit någonting. Kroppen eller "hjärnan" som Miriam säger, befinner sig i ett klassrum men frågorna handlar om mående, tankar och känslor. Här formas spänningar och rörelser kring vad det innebär att uppmanas till att göra manualens övningar sittandes i ett klassrum tillsammans med klasskamrater. De återkommande frågorna som ska besvaras skriftligt blir jobbiga och skapar förvirring. I relation till det utrymme som formas $\mathrm{i}$ nätverket av klassrum, manualer och hälsa blir frågorna omöjliga att besvara. Frågor, tankar och plats går inte ihop. Genom dessa relationer skapas utrymme med möjlighet att inte följa uppmaningen att besvara frågorna. I denna händelse framkommer hur manualen, precis som alla andra aktörer, inte fullkomligt reglerar eller ordnar det hälsofrämjande arbetet. I mötet förändras och samskapas såväl manualen som andra aktörer och blir i en samtidighet något som ska medvetandegöra negativa tankar och något som skapar förvirring och tomhet. Denna känsla av förvirring omformar manualen och ger ett utrymme att undkomma manualens anspråk och krav. Hur manualen görs och vad den kan göra tar form i relation med kroppar och 
klassrum. Här formas en materiell och diskursiv rumslighet med möjlighet för flöden och rörelser där nätverket förändras och omformas (jfr Fenwick, 2011). Dessa rörelser formas genom händelser där manualer, rum och kroppar blir aktiva på sätt som inte kan förutses eller kontrolleras. Vad manualerna gör och hur de görs blir en distribuerad process sammanvävd med de sammanhang som det ömsesidigt skapar (Gunnarsson, 2015; 2017a).

Vid den sista DISA-träffen på en av skolorna där jag deltar är klassrummet möblerat på ett nytt sätt. Rummet är iordningställt med varannan bänk och stol i en rund cirkel. Det bildar en vid cirkel och ett avstånd mellan varje elev genom att det står en bänk mellan dem. Gruppledaren Caroline berättar för mig innan DISA-träffen att idag innefattar manualen många övningar ska besvaras skriftligt så det är bra att varje elev har tillgång till en bänk för att underlätta detta.

Eleverna kommer in och sätter sig på sina angivna platser. Caroline säger 'vad allvarliga ni ser ut' och fortsätter med skämtsam ton att 'nu ska vi ha prov'. Va! utbrister några elever? $\mathrm{O} j$, nu blev det många negativa tankar, svarar Caroline. Men, vad kan man ha prov på i DISA? frågar Nicki. Jo, vilken negativ tanke kom från den händelsen och en positiv mottanke, svarar Theresia.

När eleverna möter klassrummet och dess möblering skapas ett nätverk av kroppar, stolar, bänkar och manualer. Detta formar en affektiv-atmosfär eller stämning som gruppledaren Caroline beskriver som allvarlig. Tillsammans med denna atmosfär skämtar Caroline om att de ska ha prov vilket också överensstämmer med möblernas materiella och diskursiva utformning. När eleverna reagerar med förvåning reproduceras manualens artikulationer om negativa tankar. Nicki frågar vad ett prov i DISA skulle kunna innehålla och formar därigenom en gränsdragning mot andra praktiker i skolan där prov ofta är ett givet inslag. Theresia menar att det finns ett innehåll i DISA som skulle kunna gå att ha prov på och hänvisar till de matriser som de arbetat med. Att det är den sista DISA-träffen, klassrummet, de isär ställda bänkarna, prestations- och bedömningsdiskurser och elevernas allvarliga uttryck samskapar en händelse av prov och kunskapsmätning. Denna händelse producerar ett utrymme av allvar, prov och negativa tankar sammanvävt med manualer, elever och gruppledare. Manualen görs i detta nätverk till en lärobok eller handbok som innehåller fakta och rätta svar. På så vis blir det hälsofrämjande arbetet del av en skolpraktik med ett bestämt kunskapsinnehåll och fastlagda kriterier för hur hälsa ska uppnås.

Såsom visades ovan skiljde sig också övningarna i manualen från vanligt förekommande inslag i skolan samtidigt som dess situering i skola och klassrum innebar en ständig sammanvävning med skolpraktiker. Bland annat 
de exempel i elevmanualen som utgick från tecknade serier som eleverna skulle arbeta med för att bli medvetna om sina negativa tankar. Med utgångspunkt i serien Katten Gustaf ska eleverna svara på frågor om vad som var en negativ tanke, utlösande händelse och sedan föreslå en positiv mottanke. Vid en av elevintervjuerna frågade jag vad de tänkte om dessa serier.

Emma: De var lite obekväma på nåt sätt. Nu ska vi sitta och göra en stencil om känslor och det kändes såhär.

Tanja: Det var lite oseriöst eller lite osammanhängande eller, jag vet inte hur jag ska säga.

Emma: Lite såhär vad har katten Gustav med min skolångest att göra.

När manualens frågor om tankar och känslor ställs i relation till Katten Gustav-serien menar eleverna att de blir obekväma och oseriösa. Det skapas en diskrepans eller spänning där den tecknade serien har en underhållande och roande funktion men i detta sammanhang ska förebygga ohälsa. Den skolångest som Emma beskriver blir del av och ska integreras med seriefiguren Katten Gustav som är manualens exempel. Det är manualen, och i det här fallet tecknade serier, som ges tillit att hantera och förändra elevernas tankar och känslor. Individen, dess känslor står i centrum, ska tränas och förändras, men det är manualen som i första hand ger berättelser och exempel vilket Emma menar gör att situationen blir 'obekväm'. I analysen av denna händelse framkommer hur mötet mellan elever och manual formar ett utrymme med spänningar och rörelser. Mol (2002) beskriver hur spänningar formas när olika verkligheter möts. Här formas spänningar kring hur individen görs till den aktiva och sätts $\mathrm{i}$ centrum men samtidigt blir passiviserad och marginaliserad genom att fogligt följa DISA-övningarna. Det innebär att DISA dels sätter fokus på elevernas känslor, dels är styrd av en manual med en bestämd agenda. Med dessa spänningar kan sammanstötningar uppstå med rörelser och förflyttningar. De förutbestämda antaganden som manualen insisterar på om såväl elever som verklighet omskapas i mötet. I nätverket formas utrymme för specifika tänkandekännande-kroppar att bli till och formar dess kapacitet att handla. Med denna spänning formas en affektiv koreografi där kroppar rör sig och agerar tillsammans i flöden som samtidigt ger begränsningar och möjligheter. Vad som kan tänkas-kännas-göras blir något som tar form genom provisoriska kollektiv av kroppar, affekter, materialiteter och diskurser (Gunnarsson, 2017a). 


\section{Att hinna motverka stress}

I DISA-programmet ingår att eleverna får i läxa att fylla i en sinnesstämningsdagbok. I denna sinnesstämningsdagbok ska de varje dag anteckna hur de mått eller känt sig och vilka negativa tankar de haft. Samtidigt som gruppledarna betonade att det inte var så viktigt att göra denna läxa var det ett inslag som återkommande inledde och avslutade träffarna. När det hälsofrämjande arbetet sammankopplas med klassrum, läxor och prov blir det del av en skolvardag som i många fall skapar stress och press. Det framkom vid en intervjusituation med elever:

Evelyn: Det här häftet [manualen] var tjockt och ser läskigt ut.

Janina: Man skulle inte bli stressad av DISA och så får man läxor i alla fall.

Så hur ska jag hinna med alla läxor?

Evelyn: När man ser det här paketet blir man helt upphetsad och känner va en till lektion.

I denna händelse produceras känslor av stress och upprördhet i och genom samhandlingar med manualen. Mötet mellan manualen och eleverna formar krav om prestationer och manualen görs i elevernas utsagor till ett "läskigt paket”. Det produceras stress och oro där DISA-träffen blir till ytterligare en lektion bland alla andra lektioner med läxor och måsten. Med manualen blir det ingen skillnad på det hälsofrämjande arbetet och vanliga lektioner där ett visst innehåll ska avhandlas och tränas. Det hälsofrämjande arbetet blir till ett förutbestämt paket som fungerar mer eller mindre upprepande för att arrangera denna praktik (jfr Singleton \& Law, 2013). Dess intention att främja hälsa transformeras i samhandlingar med eleverna till att skapa stress och krav.

Som framkommit i spårningen ovan förbinds och samskapas manualer, gruppledare och elever i relation till varandra och formar på så vis ett samarbete men det uppstår också friktioner och glapp. Detta framkom vid en händelse där manual, elever, gruppledare och tid formar ett nätverk med specifika temporala effekter. Vid denna DISA-träff uppstod en intensiv diskussion bland deltagarna om kändisar, reklam och kroppsideal. Efter en stund avbryter gruppledaren Nina diskussionen.

Nina: Nu går vi vidare till stressiga situationer på sida 71 .

Sofi: Men sånt här är roligt att prata om.

Nina: Ja men nu måste vi gå vidare för det här avsnittet är så långt och vi kommer precis att hinna. 
Nina hejdar diskussion för att gå vidare till nästa övning. Trots invändningar från en elev menar Nina att avsnittet innehåller så många övningar som måste hinnas med. Hur relationen mellan gruppledare och manual formas tillsammans med stress, måsten och hinna framkommer här. Det som eleven Sofi utrycker som roligt att prata om får ett begränsat utrymme när manualen uppmanar till att göra övningar om stressiga situationer. Genom att tillhandahålla långa avsnitt med många övningar formas det hälsofrämjande arbetet av att "gå vidare". Med de ramar som skoldagen tillhandahåller finns litet utrymme för diskussion. Tid blir en aktiv aktör i detta nätverk och skapar ett specifikt utrymme som tillsammans med manualen kräver att vissa prioriteringar görs (Gunnarsson, 2018). I samhandling med manualen blir det i denna händelse övningen om stressiga situationer som ges utrymme istället för elevernas önskemål. Övningarna ska hinnas med, men eleverna stör detta görande genom anspråk om att vara delaktiga och påverka innehållet (jfr Wickström, 2012). Sofis önskemål utgår från vad som är roligt och blir inte på samma vis styrt av att hinna med övningarna. I ett nätverk av skola, manualer, elever och tid har varken gruppledaren som individ eller manualen möjlighet att ensam styra träffen. Träffen tar form genom samhandlingar med en mängd aktörer (Mol, 2010). På så vis görs i nätverket olika samtidiga tider eller flera temporära rytmer och processer (Haraway, 2008; se också Bodén, 2016). Det visar hur manualens göranden inte går att förutsäga eller kontrollera utan dess samskapande kraft är flyktig och opålitlig. Manualen formas till en aktör som genom sin önskan att motverka stress blir delaktig i att skapa stress (jfr Gunnarsson, 2015; Kvist Lindholm \& Zetterqvist Nelson, 2015). Trots viss evidens och uppmätta positiva verkningar blir manualens effekter mångfacetterade och oförutsägbara. Effekten av förändring mot ökad hälsa som DISA och dess manualer vill uppnå går inte att förutbestämma och blir utifrån spårningen i denna studie svår att åstadkomma.

\section{AVSLUTANDE DISKUSSION: MANUALERS OFÖRUTSÄGBARA EFFEKTER}

Denna text inleddes med en fråga om vilka effekter skolors hälsofrämjande arbete är med och skapar. För att besvara denna fråga har jag i denna text spårat händelser $\mathrm{i}$ det manualbaserade programmet DISA med ambitionen att inkludera materialiteter och känslor som aktiva deltagare. Med aktörnätverksteori och begreppen nätverk, utrymme och blivande har ett analytiskt fokus varit att undersöka vad manualerna gör och hur de görs såsom samhandlande aktörer i skolors hälsofrämjande arbete. Det har inneburit frågor om hur manualerna blir delaktiga $\mathrm{i}$ att forma det hälsofrämjande arbetet, dess regleringar och möjligheter.

I spårningen har det framkommit hur ett hälsofrämjande arbete som innefattar manualer formar universella antaganden om elevernas hälsa, tankar 
och känslor. Återkommande avpassas och anpassas det hälsofrämjande arbetet efter manualerna i stället för att insatsen anpassas efter eleverna. Manualen görs till en trygg aktör, en aktör som tillsammans med evidens och forskning har kunskap om de aktörer som deltar och hur hälsa ska främjas. Sammankopplade i nätverk av trygghet, evidens och tid blir således manualerna reglerande och stabiliserande aktörer som erbjuder givna frågor och svar. Samtidigt blir de läskiga, obekväma, oseriösa och stressande aktörer invävda i elevernas verkligheter och kroppar. Här skapas utrymme att utmana och omforma manualernas logik och därav inte besvara dess frågor. På så vis blir manualerna både poröst konstruerade och stabilt fixerade i de olika utrymmen som formas i nätverken. Det skapas öppningar för flöden och rörelser med effekter som inte går att förutse eller kontrollera (Mol, 2011; Fenwick, 2011).

Jag återvänder avslutningsvis till Pernilla Garmys (2016) fråga om manualernas betydelse. Frågan som ställdes var om det hade blivit samma effekter med ostrukturerade träffar? Med aktörnätverks teori finns det inget svar på den frågan eftersom den är ställd utifrån en linjär logik där det är möjligt att mäta en manuals effekter och värde att förebygga hälsa, där det går att särskilja strukturerade och ostrukturerade träffar. Med den analytiska spårning som gjorts i denna text menar jag att manualer inte kan förstås såsom enbart en manual - en stabil och oföränderlig bruksanvisning vars effekter går att utvärdera och förutsäga. Manualer fungerar inte som fasta enheter som elever och lärare kan följa, lära av eller förkasta och göra motstånd mot. Mol (2011) skriver att ett redskap aldrig är oskyldigt eller neutralt utan tar form genom komplexa relationer och samhandlingar. Manualen går då att förstå som både ett verktyg med syfte att främja hälsa men också som föränderlig aktör del $\mathrm{i}$ att forma kroppar och verkligheter. I stället för att skolors hälsofrämjande arbete formas till ett laboratorium där manualer ska följas, som utgår från att eleverna är stressade och deppiga och att detta måste förändras och åtgärdas, går det att förstå hur eleverna blir stressade genom de relationer som de är del av.

Med denna förståelse av hälsofrämjande arbete blir det svårt att förutse manualers effekter och verkningar, vilka metoder som fungerar och vilka som inte gör det. Det innebär istället att förstå manualerna och dess effekter som organiska, opålitliga och flytande. En användbar metod eller manual blir då den som ger möjlighet för ett gemensamt utforskande (Gunnarsson, 2017b). Den som förmår att inkludera situationen, som erbjuder tänkande-kännande och inte enbart ett instrumentellt igenkännande (Stengers, 2005). Annemarie Mol föreslår att en omsorgsfull hälsopraktik är den "som ger rikliga tillfällen till ambivalens, oenighet, osäkerhet, missförstånd och konflikter" (2011, s. 104). Den ska innefatta engagemang och experimenterande där praktikens effekter och görande ständigt undersöks. Ingen färdig eller perfekt praktik 
eftersträvas utan en praktik där många olika berättelser och världar kan ta form.

\section{NOTER}

${ }^{1}$ Se Moberg (2017, s. 24) som beskriver hur ANT tillhandahåller en sammanvävning av teoretiska och metodologiska principer.

${ }^{2}$ För en mer utförlig genomgång av det empiriska materialet se Gunnarsson (2015, s. 82).

3 För att säkerställa deltagarnas anonymitet är alla namn pseudonymer. Se Gunnarsson (2015) för en redogörelse och diskussion kring studiens forskningsetiska ställningstaganden.

\section{REFERENSER}

Bergh, Andreas \& Englund, Tomas (2014). A changed language of education with new actors: the authorization of promotion and prevention programmes in Swedish schools. Journal of Curriculum Studies, 46(6), 778-797.

Biesta, Gert (2007). Why “what works” won't work: evidence-based practice and the democratic deficit in educational research. Educational Theory, 57(1), 1-22.

Bodén, Linnea (2016). Dexter time: the space, time, and matterings of school absence registration. Discourse: Studies in the Cultural Politics of Education, 37(2), 245-255.

Brunila, Kristiina (2014). The rise of the survival discourse in an era of therapisation and neoliberalism. Education Inquiry, 5(1), 7-23.

Ecclestone, Kathryn (2015). Vulnerability and wellbeing in educational settings: the implications of a therapeutic approach to social justice. I Wright, Kathryn \& McLeod, Julie (red.) Retbinking Youth Wellbeing: Critical Perspectives. Singapore: Springer.

Elevmanual (2011). DIS A: en metod för tonåringar $i$ att hantera stress och påfrestningar. Clarke, G., Lewinsohn, PM, Lindberg, L, Svensson, J., Treutiger, BM, Koertege J. \& Thoomas, EM. Elektronisk resurs http://www.folkhalsoguiden.se/disa (hämtad 110501).

Fenwick, Tara (2011). Reading educational reform with Actor Network theory: fluid spaces, otherings, and ambivalences. Educational Philosophy and Theory, 43(1), 114134.

Ferrer-Wreder, Laura, Stattin, Håkan, Cass Lorante, Carolyn, Tubman, Jonathan \& Adamson, Lena (2005). Framgängsrika preventionsprogram för barn och unga: en forskningsöversikt. Stockholm: Gothia. 
Garmy, Pernilla (2016). Hälsopromotion i skolan: utvärdering av DIS A: ett program för att förebygga depressiva symtom hos ungdomar. Diss. (sammanfattning) Lund: Lunds universitet.

Gruppledarmanual (2011). DIS A: en metod för tonåringar $i$ att hantera stress och påfrestningar. Clarke, G., Lewinsohn, PM, Lindberg, L, Svensson, J., Treutiger, BM, Koertege J. \& Thoomas, EM. Elektronisk resurs http://www.folkhalsoguiden.se/disa (hämtad 110501).

Gunnarsson, Karin (2015). Med önskan om kontroll: figurationer av bälsa i skolors hälsofrämjande arbete. Diss. Stockholm: Stockholms Universitet.

Gunnarsson, Karin (2017a). Möten och rörelser i affektiva koreografier. I Bergstedt, Bosse (red.) Posthumanistisk pedagogik: teori, undervisning och forskningspraktik (s. 2540). Malmö: Gleerups.

Gunnarsson, Karin (2017b). Potentiality for change? Revisiting an action research project with a sociomaterial approach. Educational Action Research, 1-16.

Gunnarsson, Karin (2018). Responding with care: a careful critical approach within educational health promotion." Reconceptualizing Educational Research Methodology, 9 (1), 17-28.

Haraway, Donna (2004). The Haraway reader. New York, London: Routledge.

Haraway, Donna (2008). When species meet. University of Minnesota press.

Haraway, Donna (2011). När arter möts (övers. Ylva Gislén). Fronesis, No. 35, 174203.

Irisdotter Aldenmyr, Sara (red.) (2014). Hyfs, bälsa och gemensamma värden: Studier av skolans komplexa värdegrunds- och fostransuppdrag. Malmö: Gleerups.

Jablonska, Beata \& Heinemans, Nelleke (2011). Metodtrohet $i$ det främjande och förebyggande hälsoarbetet i skolan. SET- och DIS A-metoden. Rapport, Karolinska Institutet.

Kvist Lindholm, Sofia \& Zetterqvist Nelson, Karin (2015). “Apparently I've got low self-esteem": schoolgirls' perspectives on a school-based public health intervention. Children \& Society, 29(5), 473-483.

Lather, Patti \& St. Pierre, Elizabeth (2013). Post-qualitative research. International journal of qualitative studies in education, 26(6), 629-633.

Latour, Bruno (2005). Reassembling the social: an introduction to actor-network-theory. Oxford: University Press.

Moberg, E. (2017). Breakdowns, overlaps and ambivalence: an Actor-network theory study of the Swedish preschool curriculum. Diss. (sammanfattning) Stockholm: Stockholms universitet.

Mol, Annemarie (2002). The body multiple: ontology in medical practice. Durham: Duke University Press. 
Mol, Annemarie (2006). Proving and improving: on health care research as a form of self-reflection. Qualitative Health Research, 16(3), 405-414.

Mol, Annemarie (2010). Actor-network theory: sensitive terms and enduring tensions. Kölner Zeitschrift für Soziologie und Sozialpsychologie, 50(1), 253-269.

Mol, Annemarie (2011). Omsorgens logik: aktiva patienter och valfrihetens gränser. Lund: Arkiv.

SBU (2010). Program för att förebygga psykisk obälsa hos barn. En systematisk. litteraturöversikt. Stockholm: Statens beredning för medicinsk utvärdering (SBU).

Seigworth, Gregory \& Gregg, Melissa (2010). An inventory of shimmers. I Gregg, Melissa \& Seigworth, Gregory (red.) The affect theory reader. Durham [N.C.]: Duke University Press.

Singleton, Vicky \& Law, John (2013). Devices as rituals: notes on enacting resistance. Journal of Cultural Economy, 6(3), 259-277.

Skolinspektionen (2015). Elevhälsa: elevers behov och skolans insatser. Kvalitetsgranskning, Rapport 2015:05.

Skolverket (2011). Förskolans och skolans värdegrund: förbållningssätt, verk.tyg och metoder. Stockholm: Skolverket.

Skolverket (2016). Delredovisning av uppdrag om att genomföra insatser för att förbättra det förebyggande och hälsofrämjande arbetet inom elevhälsan i syfte att stödja elevernas utveckling mot utbildningens mål. Redovisning av regeringsuppdrag, Dnr: 2016-1616.

Stengers, Isabelle (2005). Introductory notes on an ecology of practices. Cultural Studies Review, 11(1), 183-196.

Treutiger, Britt-Marie \& Lindberg, Lene (2012). Prevention of depressive symptoms among adolescent girls. In Andershed, Anna-Karin (red.) Girls at risk: Swedish longitudinal research on adjustment. New York: Springer

Wickström, Annette (2012). From individual to relational strategies: transforming a man-ual-based psychoeducational course at school. Childhood, 20(2), 215-228.

Wright, Kathryn (2015). From targeted interventions to universal approaches: historicizing wellbeing. In Wright, Kathryn \& McLeod, Julie (red.) Retbinking Youth Wellbeing: Critical Perspectives. Singapore: Springer. 